\title{
Rehabilitasi Sosial di Panti Sosial Karya Wanita Andam Dewi Sukarami Kabupaten Solok
}

\author{
Dwi Monica Angela, Azwar Ananda, Fatmariza \\ Program Studi Pendidikan Pancasila dan Kewarganegaraan \\ Universitas Negeri Padang \\ E-mail : angeladwi12@yahoo.co.id
}

\begin{abstract}
ABSTRAK
Artikel ini bertujuan untuk mendeskripsikan rehabilitasi sosial di Panti Sosial Karya Wanita Andam Dewi Sukarami Kabupaten Solok. Penelitian ini dilakukan di Sukarami Kabupaten Solok. Penelitian ini menggunakan metode kualitatif dengan pendekatan deskriptif. Penentuan informan menggunakan teknik purpossive sampling. Jenis datanya adalah data primer dan sekunder yang dikumpulkan dengan wawancara dan studi dokumentasi. Uji keabsahan data melalui teknik triangulasi dan membercheck. Sedangkan teknik analisis data menggunakan teknik analisa Miles dan A Hubberman. Dari hasil penelitian ditemukan bahwa proses rehabilitasi sosial di PSKW Andam Dewi mencakup bimbingan kepribadian, kerohanian dan keterampilan sebagai bekal kehidupan yang lebih baik dan berguna bagi warga binaan setelah keluar nanti. Meskipun begitu tidak dapat dipungkiri bahwa ada kendala yang ditemukan dalam menjalankan proses rehabilitasi diantaranya sarana dan prasarana yang kurang memadai, keterbatasan dana, kurangnya jumlah instruktur dan masalah dari warga binaan sosial itu sendiri. Adapun upaya yang dilakukan untuk menghadapi kendala tersebut adalah dengan memanfaatkan dana yang ada dari pemerintah seoptimal mungkin untuk melengkapi segala bentuk sarana dan prasarana yang dibutuhkan untuk menunjang proses rehabilitasi dan kerja sama antara instruktur dengan warga binaan agar proses pembinaan dapat berjalan sesuai dengan tujuan yang diharapkan.
\end{abstract}

\section{Kata Kunci : Rehabilitasi, Wanita Tuna Susila, PSKW Andam Dewi}

\section{ABSTRACT}

This article aims to describe the The Social Rehabilitation at the Social House "Karya Wanita Andam Dewi", Sukarami, Solok Regency. It used the qualitative method of descriptive approach. Purposive sampling technique was used to determine informants. The types of data are primary and secondary data which are collected through interviews and documentation studies. The test of data validity is done through triangulation technique and member check. While the data analysis techniques used the analytical technique of Miles and A.Hubberman.The results of the research show that the process of social rehabilitation at PSKW Andam Dewi includes guidance of personality, spirituality, and skills as a provision of a better life and useful for the assisted citizens after going out later. Nevertheless, it can not be denied that there are obstacles found in carrying out the rehabilitation process such as inadequate facilities and infrastructures, lack of funds, lack of numbers of instructors and 
Rehabilitasi Sosial di..

problems from social assisted citizens themselves. The efforts to handle these obstacles are: utilize government' existing funds as optimal as possible to complete all of the facilities and infrastructures which are needed to support the process of rehabilitation and cooperation between instructors and assisted citizens so that the coaching process can run in accordance with the expected goals.

\section{Keywords : Rehabilitation, Prostitutes, PSKW Andam Dezwi}

\section{PENDAHULUAN}

Kehidupan masyarakat Indonesia merupakan kehidupan yang sangat kompleks dengan adanya berbagai masalah sosial yang melanda beberapa masyarakat yang ada di Indonesia. Adanya berbagai permasalahan sosial yang di hadapi masyarakat itu sendiri membuat mereka hidup tidak normal atau tidak semestinya seperti rendahnya ekonomi dalam memenuhi kebutuhan hidup. Permasalahan sosial adalah beberapa kondisi yang terlahir dari sebuah keadaan masyarakat yang tidak dapat berfungsi sebagaimana mestinya yang sehingga mengakibatkan kekecewaan dan penderitaan (Soekanto, 2003).

Permasalahan sosial itu muncul karena di pengaruhi oleh tidak meratanya kesejahteraan sosial, dimana seseorang atau masyarakat yang tidak mendapatkan kehidupan sosial yang layak. Dalam hal ini yang sering mengalami permasalahan sosial biasanya kaum perempuan, salah satunya penyandang masalah kesejahteraan sosial yaitu wania tuna

susila. Masalah Wanita Tuna Susila (WTS) di Indonesia merupakan salah satu masalah sosial yang kompleks karena perbuatannya tersebut menyimpang dari norma-norma atau nilai-nilai yang berlaku dalam masyarakat. Banyak istilah yang digunakan untuk menyebut WTS ini

seperti Pelacur, Balon, Sundel dan Kupu-kupu Malam. Pelacur adalah seseorang yang melacur di dunia pelacuran (Koentjoro, 2004).

Permasalahan Wanita Tuna Susila di Sumatera Barat walaupun secara kuantitas relatif kecil, namun pada pandangan masyarakat dianggap sebagai masalah yang besar. Struktur budaya Minangkabau dimana adat dan agama mempunyai fungsi sebagai norma sosial yang dominan, Sebagai realisasinya pada tahun 2017, Pemerintah Daerah Sumatera Barat mengkoordinasikan beberapa Instansi terkait melakukan operasi kejutan (razia) terhadap para Wanita Tuna Susila. Pada tahun 2017 tersebut terjaring sebanyak 70 orang Wanita Tuna Susila, kepada mereka diberikan nasehat dan bimbingan agar tidak melakukan perbuatannya dan selanjutnya dikembalikan kepada keluargannya. Untuk mendukung upaya Pemda Sumatera Barat dalam menanggulangi masalah WTS, maka Pemerintah Pusat menyetujui Pendirian panti sosial untuk menampung dan merehabilitasi Wanita Tuna Susila.

Permasalahan Wanita Tuna Susila di Sumatera Barat walaupun secara kuantitas relatif kecil, namun 
pada pandangan masyarakat dianggap sebagai masalah yang besar. Struktur budaya Minangkabau dimana adat dan agama mempunyai fungsi sebagai norma sosial yang dominan, Sebagai realisasinya pada tahun 2017, Pemerintah Daerah Sumatera Barat mengkoordinasikan beberapa Instansi terkait melakukan operasi kejutan (razia) terhadap para Wanita Tuna Susila. Pada tahun 2017 tersebut terjaring sebanyak 70 orang Wanita Tuna Susila, kepada mereka diberikan nasehat dan bimbingan agar tidak melakukan perbuatannya dan selanjutnya dikembalikan kepada keluargannya. Untuk mendukung upaya Pemda Sumatera Barat dalam menanggulangi masalah WTS, maka Pemerintah Pusat menyetujui Pendirian panti sosial untuk menampung dan merehabilitasi Wanita Tuna Susila.

Panti Sosial Karya Wanita "Andam Dewi" Solok merupakan salah satu Unit Pelaksanaan Teknis Dinas (UPTD) Dinas Sosial Provinsi Sumatera Barat yang menitikberatkan pada fungsi pelayanan sosial, diharapkan dapat memberikan kontribusi dalam pengentasan penyandang masalah kesejahteraan sosial mulai dari tahap pendekatan awal sampai dengan terminasi. Kegiatan pelayanan rehabilitasi sosial bagi wanita tuna susila yang dilaksanakan di PSKW Andam Dewi Solok, dimaksudkan untuk memperoleh hasil penanganan yang optimal dalam upaya mencapai sasaran program pelayanan dan rehabilitasi sosial serta adanya keterpaduan langkah pelaksanaanya.
Program pelayanan dan rehabilitasi sosial bagi wanita tuna susila ini yaitu memulihkan kondisi fisik, mental, psikis, sosial, sikap dan perilaku wanita tuna susila agar mereka mampu melaksanakan fungsi sosial secara wajar dalam kehidupan keluarga maupun dalam masyarakat. Dalam proses rehabilitasi sosial terdapat beberapa bimbingan fisik dan mental yang didapat dengan membina ketaqwaan melalui pengajaran agama dalam hal shalat, menggunakan jilbab bagi setiap wanita yang muslim lewat arahan hal terkait agama mereka mampu menggunakan jilbab nantinya, hal ini sesuai dengan nilai budaya yang berlaku pada masyarakat Minangkabau yang mayoritas muslim dan menggunakan jilbab pada kehidupan sehari-hari.

Begitu juga halnya dengan bimbingan sosial yang diperoleh lewat membina kesadaran akan tanggung jawab dalam hubungan sosial, serta bimbingan keterampilan dalam hal ini pembekalan keterampilan dan keahlian yang dapat dikembangkan nantinya dalam menjalani kehidupan setelah keluar panti sosial ini seperti dalam dunia kerja maupun dunia usaha. Banyak pengajaran dan bimbingan yang sangat berguna bagi WTS dalam menjalani setiap kegiatan selama proses rehabilitasi sosial disini.

Kehadiran PSKW Andam Dewi ini seharusnya juga berpengaruh dalam upaya pemerintah dalam mencegah prostitusi yang jumlahnya semakin meningkat namun Panti Sosial Karya Wanita tidak begitu dimanfaatkan secara baik bagi beberapa WTS yang menjalani rehabilitasi sosial karena masih adanya 
Rehabilitasi Sosial di..

WTS yang pernah menjalani rehabilitasi sosial disini kembali terjebak pada dunia prostitusi lagi dan masuk untuk yang kedua kalinya bahkan yang ketiga kali kembali ke PSKW Andam Dewi ini.

Data yang didapatkan dari pihak PSKW Andam Dewi pada rentang waktu Februari-Maret 2017 ada 5 orang WTS yang setelah selesai dan dipulangkan seusai menjalani rehabiltasi sosial kembali masuk pada bulan Agustus 2017 untuk menjalani rehabilitasi sosial untuk kedua kalinya, karena kembali terjaring razia oleh Satpol-PP kembali. Selain perihal diatas lewat data masih banyaknya yang belum menyadari manfaat rehabiltasi, hal ini dapat dilihat dari data PSKW Andam Dewi ini pada 2016-2017 ditemukan kasus WTS yang melarikan diri sebanyak 23 orang yang disebabkan tidak mau menjalani rehabiltasi di Panti Sosial Karya Wanita Andam Dewi ini. Rehabilitasi dianggap hal yang menakutkan dan penuh aturan adalah hal yang terbayang bagi WTS yang melarikan diri.

Dari beberapa uraian diatas maka peneliti merasa masalah tersebut penting untuk diteliti. Olah karena itu peneliti memberi judul penelitian ini "Rehabilitasi Sosial Di Panti Sosial Karya Wanita Andam Dewi Sukarami Kabupaten Solok".

\section{METODE PENELITIAN}

Metode yang digunakan dalam penelitian ini adalah penelitian kualitatif dengan pendekatan deskriptif. Lokasi Penelitian di Nagari Sukarami Kecamatan Gunung Talang Kabupaten Solok dengan informan penelitian Kepala PSKW Andam Dewi,
Personil PSKW, Instruktur bimbingan dan Warga binaan sosial di PSKW Andam Dewi . Lalu jenis data yang digunakan yaitu Data Primer dan Data Sekunder. Kemudian Teknik pengumpulan data yaitu wawancara dan studi dokumentasi dengan menggunakan alat pengumpulan data seperti pedoman wawancara, handphone dan buku catatan. Selanjutnya teknik pengujian keabsahan data dengan menggunakan teknik triangulasi sumber data dan yang terakhir teknik analisis data menggunakan tahap analisa Milles dan A Hubberman (Sugiyono, 2012)

\section{HASIL DAN PEMBAHASAN}

1. Proses Pembinaan Mental, Soial Dan Keterampilan WBS Melalui Rehabilitasi Sosial Di Panti Sosial Karya Wanita Andam Dewi Sukarami Kabupaten Solok

Pada dasarnya pembinaan di artikan sebagai kegiatan yang dilakukan untuk memperoleh hasil yang maksimasl dan memiliki mamfaat yang positif. Pembinaan bukan hanya di artikan sebagai bentuk kegiatan yang dilaksanakan demi tercapainya hasil yang baik namun pembinaan dapat di artikan sebagai pengelolaan kegiatan dari awal sampai akhir kegiatan. Lebih luas Kemensos menguraikan tahapan pelayanan pelaksanaan dalam rehabilitasi sosial adalah bimbingan fisik, bimbingan mental spiritual, bimbingan sosial, bimbingan kecerdasan dan keterampilan kerja, bimbingan belajar kerja atau usaha, bimbingan kesiapan dan partisipasi keluarga, bimbingan kesiapan partisipasi masyarakat, penyaluran, pembinaan lanjut.

Pembinaan terhadap warga binaan sosial merupakan masalah 
yang sangat kompleks mengingat orang-orang yang terlibat dalam masalaha ini bukan hanya orang dewasa akan tetapi anak dibawah umur pun terjaring kedalam masalah sosial ini. Pembinaan yang dilakukan di Panti Sosial Karya Wanita Andam Dewi Sukarami adalah sebagai berikut:

\section{Bimbingan Kepribadian}

Bimbingan kepribadian adalah memberi pembinaan agar warga binaan dapat menyadari kesalahannnya dan tidak terkucilkan dengan warga binaan lainnya. Dan pada akhirnya diharapkan bagi ex wanita tuna susila nantinya memiliki budi pekerti yang luhur sehingga tidak terasingkan dilingkungan masyarakat. Seperti hasil wawancara dengan ibuk Daarfutri selaku instruktur bimbingan sosial dan kepribadian yang mana pembinaan atau bimbingan kepribadian adalah pembinaan yang ditujukan kepada warga binaan agar dapat menyadari kesalahannya dimasa lalu dan untuk membentuk kepribadian sebagai bekal apabila telah keluar dari Panti Sosial Karya Wanita Andam Dewi Sukarami.

2. Bimbingan Kerohanian

Pembinaan atau bimbingan kerohanian adalah usaha yang diperlukan agar diteguhkan imannya terutama memberi pengertian agar warga binaan dapat menyadari akibatakibat dari perbuatan-perbuatan yang benar dan perbuatan-perbuatan yang salah. Bimbingan kerohanian yang ada di Panti Sosial Karya Wanita Andam Dewi Sukarami adalah sepeti baca tulis Al-Quran, bimbingan pelaksanaan ibadah, ceramah agama dan konseling mengenai masalah keagamaan.

Bimbingan kerohanian yang diberikan wajib diikuti oleh seluruh warga binaan setiap harinya, namun berdasarkan hasil penelitian saya ditemukan bahwa masih ada warga binaan yang tidak mengikuti bimbingan kerohanian dengan berbagai macam alasan, padahal seharusnya setiap warga binaan wajib mengikutinya karena bimbingan kerohanian sangat penting agar warga binaan dapat menyadari kesalahannya dan tidak mengulangi kembali perbuatan yang pernah dilakukannya dulu.

3. Bimbingan keterampilan

Bimbingan keterampilan mencakup kepada kegiatan belajar menjahit, bordir, tata boga, pertanian, kerajinan tangan / handycraf. Keterampilan ini diharapkan agar nanti setelah keluar dari Panti Sosial Karya Wanita Andam Dewi Sukarami setiap warga binaan memiliki keterampilan yang bisa mereka jadikan sebagai pekerjaan untuk melanjutkan hidupnya nanti. Kegiatan keterampilan ini bebas dipilih oleh warga binaan sesuai dengan bakat dan minatnya masingmasing. Kegiatan keterampilan ini wajib dilakukan oleh setiap warga binaan agar mereka memiliki bekal serta keahlian dibidang tersebut yang dapat disalurkan dan dikembangkan nantinya sehingga warga binaan tersebut tidak akan canngung lagi dan dapat bekerja setelah keluar dari Panti Sosial Karya Wanita Andam Dewi Sukarami dengan keahlian yang mereka dapat selama menjalani proses rehabilitasi.

2. Kendala yang ditemui dalam Proses Pembinaan WBS Melalui Rehabilitasi Sosial Di Panti Sosial Karya Wanita Andam Dewi Sukarami Kabupaten Solok 
Rehabilitasi Sosial di..

Menurut Ichwan Muis ada tiga Macam Model Pelayanan Rehabilitasi sosial yaitu: Institusional Based Rehabilitation, Extra-institusional Based Rehabilitation, dan Community Based Rehabilitation. PSKW Andam Dewi Sukarami adalah salah satu model pelayanan rehabilitasi Institusional Based Rehabilitation. Di dalam menjalani proses rehabilitasi ditemukan kendala-kendala yang menghambat jalannya proses rehabilitasi terhadap warga binaan, beberapa kendala tersebut diantaranya adalah sebagai berikut:

\section{Sarana dan Prasarana yang kurang memadai}

Dilihat dari segi sarana dan prasarana di di Panti Sosial Karya Wanita Andam Dewi Sukarami Kabupaten Solok, bangunan di Panti Sosial Karya Wanita Andam Dewi dapat dikatakan kurang layak. Kendala dari segi sarana dan prasarana adalah jumlah warga binaan yang semakin banyak sedangkan jumlah asrama atau wisma tidak ditambah yaitu 2 wisma bagi warga binaan yang setiap kamarnya dihuni oleh 20-25 warga binaan dengan luas 3x4 m setiap kamarnya, sehingga menyebabkan over capacitas didalam Panti Sosial Karya Wanita Andam Dewi Sukarami yang dapat mengganggu keamanan dan kenyamana warga binaan PSKW Andam Dewi.

2. Keterbatasan Dana

Pelaksanaan pembinaan warga binaan sosial tentu saja membutuhkan biaya yang tidak sedikit. Dana yang diperoleh di Panti Sosial Karya Wanita Andam Dewi Sukarami Kabupaten Solok diperoleh dari APBD Provinsi Sumatra Barat, namun anggaran yang telah disediakan tersebut belum cukup untuk menunjang seluruh kegiatan yang akan dilaksanakan dalam proses pembinaan atau rehabilitasi. Banyaknya jumlah warga binaan juga membuat proses pembinaan menjadi semakin suklit dilakukan karena proses pembinakan atau proses rehabilitasi tetap berjalan sedangkan dana yang ada masih tetap.

3. Kurangnya jumlah instruktur

Kendala yang ditemui di Panti Sosial Karya Wanita Andam Dewi Sukarami dari segi petugas adalah kurangnya petugas yang memberikan pembinaan di bidang kerohanian dan keterampilan. Berdasarkan hasil penelitian yang peneliti temukan bahwa pada saat ini tidak ada instruktur tetap dalam pembinaan kerohanian, dimana hanya menjalin kerja sama dengan pegawai KUA Kecamatan Gunung Talang. Jadi yang memberikan pembinaan kerohanian hanya pegawai KUA saja dan dibantu oleh Ustad Mushalla Annisa di di Panti Sosial Karya Wanita Andam Dewi Sukarami Kabupaten Solok. Selain itu juga terdapat kurangnya instruktur di bidang keterampilan yang mana di dalam di Panti Sosial Karya Wanita Andam Dewi Sukarami Kabupaten Solok Cuma ada dua orang instruktur. Hal tersebut tentu saja tidak sebanding dengan jumlah warga binaan dengan lamanya waktu pelaksanaan kegiatan keterampilan.

4. Warga binaan sosial

Proses pembinaan yang dilakukan di Panti Sosial Karya Wanita Andam Dewi Sukarami Kabupaten Solok tidak akan bisa berjalan dengan lancar apabila tidak ada kerja sama yang baik antar pihak, pihak-pihak yang terkait adalah mereka yang berada dibawah lingkungan di Panti Sosial Karya Wanita Andam Dewi Sukarami yaitu 
instruktur dan warga binaan itu sendiri. Namun setelah instruktur PSKW Andam Dewi telah berupaya melakukan pembinaan yang lebih baik akan tetapi masih ada warga binaan yang tidak mau mengikuti kegiatan pembinaan tersebut. Data yang ditemukan bahwa masih ada warga binaan yang tidak mau mengikuti bimbingan kerohanian, sedangkan bimbingan kerohanian tersebut sangat penting untuk membuat warga binaan tersebut bisa menjadi lebih baik, menyadari kesalahan yang telah dibuatnya dan tidak akan mengulanginya lagi. Selain itu dalam bidang keterampilan masih banyak warga binaan yang tidak mau mengikuti kegiatan tersebut padahal kegiatan keterampilan itu sangat penting untuk menjadi bekal keterampilan dan juga bisa dijadikan pekerjaan setelah keluar dari di Panti Sosial Karya Wanita Andam Dewi Sukarami Kabupaten Solok.

3. Upaya yang dilakukan untuk menanggulangi kendala yang dihadapi dalam proses pembinaan WBS melalui rehabilitasi sosial di PSKW Andam Dewi Sukarami Kabupaten Solok.

$\begin{array}{ccr}\text { Adapun } & \text { upaya } & \text { untuk } \\ \text { menanggulangi } & \text { kendala } & \text { yang }\end{array}$ dihadapi dalam proses pembinaan WBS melalui rehabilitasi sosial di PSKW Andam Dewi Sukarami Kabupaten Solok adalah sebagai berikut :

1. Sarana prasarana yang kurang memadai

Untuk mengatasi masalah wisma atau asrama jumlah wisma belum bisa dilakukan karena keterbatasan dana, usaha yang dapat dilakukan yaitu dengan menempatkan warga binaan seoptimal mungkin didalam wisma atau asrama.

\section{Keterbatasan Dana}

Untuk memperoleh tambahan dana dalam pelaksanaan program pembinaan atau rehabilitasi PSKW Andam Dewi Sukarami mengadakan pengusulan atau pengajuan proposal kepada kementrian sosial melalui dinas sosial provinsi Sumatra Barat. Selain itu pihak PSKW Andam Dewi dalam melaksanakan pembinaan terhadap WBS melakukan penggunaan biaya seomptimal mungkin sesuai dengan kebutuhan.

3. Kurangnya jumlah instruktur

Upaya yang dilakukan dari segi petugas, PSKW Andam Dewi Sukarami melakukan beberapa cara yaitu:

1) Memberi kesempatan kepada instruktur PSKW Andam Dewi Sukarami untuk melakukan pelatihan baik dibidang pembinaan kerohanian maupun dibidang keterampilan.

2) Melakukan penambahan instruktur sesuai dengan disiplin ilmu yang dibutuhkan pihak PSKW Andam Dewi Sukarami melalui tes CPNS.

3) Mengadakan kerja sama dengan instansi pemerintah dan LSM dalam melakukan penyuluhan bagi warga binaan social

4. Warga binaan sosial

Upaya yang dilakukan untuk mengatasi kendala dari warga binaan yang tidak mau mengikuti kegiatan pembinaan rohani yaitu dengan memberikan sanksi berupa teguran dan memberikan sanksi berupa halafan ayat-ayat pendek, begitu juga hal nya dengan WBS yang tidak mengikuti kegiatan keterampilan, 
Rehabilitasi Sosial di..

karena pembinaan keterampilan itu sangat penting bagi WBS agar dapat menjadi bekal bagi mereka setelah keluar dari PSKW Andam Dewi Sukarami.

\section{KESIMPULAN}

a. Proses pelaksanaan kegiatan pembinaan terhadap warga binaan sosial di Panti Sosial Karya Wanita Andam Dewi Sukarami Kabupaten Solok, terdiri dari beberapa bimbingan diantaranya: bimbingan mental, bimbingan sosial dan bimbingan keterampilan. Bimbingan keterampilan meliputi kegiatan menjahit, bordir, pelatihan handycraft, memasak dan berkebun.

b. Terdapat banyak kendala yang dihadapi oleh petugas maupun pihak yang terlibat dalam pelaksanaan proses pembinaan WBS melalui Rehabilitasi Sosial di Panti Sosial Karya Wanita Andam Dewi Sukarami ini di antaranya, sarana prasarana yang kurang memadai untuk menunjang terlaksananya proses pembinaan WBS melalui Rehabilitasi Sosial di Panti Sosial Karya Wanita Andam Dewi Sukarami Kabupaten Solok. Masalah dana juga menjadi kendala dalam proses pembinaan karena mengganggu kegiatan pembinaan, maka dengan itu tidak bisa dilakukan banyak inovasi dalam kegiatan pembinaan. Kurangnya instruktur dan masalah yang datang dari warga binaan itu sendiri

c. Upaya yang dilakukan untuk mengatasi kendala yang di hadapi yaitu pihak panti mengajukan proposal kepada Kementerian Sosial melalui Dinas Sosial Provinsi Sumatera Barat namun sampai sekarang ini belum ada hasilnya, jadi upaya yang dapat dilakukan sementara waktu yaitu dengan menggunakan dana yang ada seoptimal mungkin sesuai dengan kebutuhan agar proses pembinaan bisa berjalan sesuai dengan yang di harapkan.

\section{DAFTAR PUSTAKA}

Koentjoro. 2004. On The Spot Tutur Dari Sarang Pelacur, Yogyakarta: Tinta

Kartini. 2016. Program Pengelolaan Dan Pembinaan Eks-Wanita Tuna Susila (Wts) Pada Pusat Pelayanan Sosial Karya Wanita (Ppskw) Mattiro Deceng Kota Makassar. Administrasi Publik. Vol 2 : hal 49-53.

Murni, Rauda. 2016. Peran Jejaring Kerja Dalam Pelaksanaan Pelayanan dan Rehabilitasi Sosial Terhadap Gelandangan dan Pengemis di Panti Sosial Bina Karya Pangudi Luhur Bekasi). Sosio Konsepsia. Vol 5: hal 48-49.

Ramadhani, Widya Suci. 2017. Proses Rehabilitasi Sosial Wanita Tuna Susila Di Balai Rehabilitasi Sosial Karya Wanita (Brskw) Palimanan Kabupaten Cirebon. Penelitian dan PKM. Vol 4 : hal 129-389.

Sugiyono. 2012. Metode Penelitian Kuantitatig Kualitatif Dan RED. Bandung: Alfabeta. Soekanto, Soerjono. 2003. Sosiologi Suatu Pengantar, Jakarta: PT. Raja Grafindo Persada 

